\title{
ELEKTRONICZNA PLATFORMA GROMADZENIA, ANALIZY I UDOSTĘPNIANIA ZASOBÓW CYFROWYCH O ZDARZENIACH MEDYCZNYCH W ŚWIETLE USTAWY O SYSTEMIE INFORMACJI W OCHRONIE ZDROWIA
}

\begin{abstract}
WSTĘP
Systemy informacyjne w ochronie zdrowia odgrywają bardzo ważną rolę w rozwiązywaniu problemów szeroko pojętego zdrowia publicznego, a także zarządzania i finansów. Znajdują one coraz większe zastosowanie zarówno w skali makrosystemowej - na poziomie kraju, regionów czy województw, jak i w skali mikrosystemowej - we wszelkiego rodzaju organizacjach zdrowotnych. W jednym i w drugim przypadku ich celem jest dostarczenie niezbędnych baz danych i przetworzenie zawartych w nich informacji dla określonych potrzeb. Rola informacji w rozwiązywaniu problemów zdrowia publicznego, podobnie jak w każdej innej dziedzinie, jest szczególna. Jest ona podstawą do podejmowania trafnych i racjonalnych decyzji. Formułowanie i realizacja programów strategicznych w dziedzinie ochrony zdrowia wymaga szerokiego zastosowania systemów gromadzenia i wymiany informacji medycznych. Również wykorzystanie tych systemów dla potrzeb efektywnego zarządzania operacyjnego organizacjami zdrowotnymi jest nieodzowne i nieuniknione.

Dokumentacja medyczna dotycząca zdrowia pacjentów jest tworzona przez każdą jednostkę ochrony zdrowia (m.in. podczas badań kontrolnych, wizyt u lekarza rodzinnego, wizyt w laboratoriach, pobytu w szpitalu, wizyty u lekarza specjalisty). W Polsce dokumentację przechowuje się $\mathrm{w}$ formie papierowej lub elektronicznej zazwyczaj w miejscu jej utworzenia. Rozproszenie dokumentacji po różnych jednostkach powoduje, że transfer dokumentów (np. pomiędzy laboratorium a lekarzem specjalistą, którzy znajdują się w różnych jednostkach ochrony zdrowia) spoczywa zazwyczaj na pacjentach.
\end{abstract}


Często wiedzę na temat lokalizacji własnej dokumentacji medycznej posiada jedynie pacjent. Dlatego trudno jest zebrać wszystkie dokumenty dotyczące jednej osoby w jednym miejscu. W diagnostyce medycznej spojrzenie na historię leczenia umożliwia postawienie trafniejszego rozpoznania choroby. W nagłych przypadkach, gdy pacjent jest nieprzytomny, dostęp do danych medycznych może uratować życie, na przykład gdy zachodzi potrzeba podania leku, na który uczulonych jest wielu ludzi.

Stworzenie spójnego krajowego systemu zarządzania dokumentami zdrowotnymi (medycznymi), a także systemów pomocniczych pozwalających na zarządzanie aktywami w szpitalach umożliwia wprowadzenie oszczędności. W Polsce nawet kilkuprocentowe zasoby w systemie ochrony zdrowia przekładają się na wielomiliardowe oszczędności. Systemy informatyczne pozwalające na prowadzenie przetargów wyłaniających dostawców usług medycznych, systemy recept elektronicznych, systemy elektronicznej rejestracji oraz inne systemy do zarządzania pozwalają na wykrywanie anomalii i nadzór nad jednostkami ochrony zdrowia. W dalszej perspektywie kompleksowe zbieranie takich danych ułatwi działania epidemiologiczne, profilaktyczne i promocję zdrowia oraz pozwoli na właściwą alokację środków finansowych.

System taki powinien być skonstruowany w sposób spełniający następujące wymagania:

- uwierzytelnianie i autoryzacja - weryfikacja deklarowanej tożsamości i przyznawanie praw dostępu;

- integralność - zachowanie spójności danych i wykrywanie zmian;

- wiarygodność - weryfikator jest w stanie uzyskać dowód, który nie może być podrobiony, a który potwierdza integralność i pochodzenie danych;

- poufność - dane nie moga zostać ujawnione niepowołanym osobom czy systemom;

- zgoda - uzyskiwanie, zapisywanie i śledzenie świadomej zgody pacjenta na dostęp do jego danych medycznych;

- audyt - wszystkie działania powinny być rejestrowane w porządku chronologicznym.

Celem artykułu jest przedstawienie rozwiązań legislacyjnych dla procesu tworzenia Elektronicznej Platformy Gromadzenia, Analizy i Udostępniania Zasobów Cyfrowych o Zdarzeniach Medycznych w Polsce w kontekście procesów integracyjnych w sektorze ochrony zdrowia w ramach Unii Europejskiej. W pracy podjęto również polemikę z proponowanymi rozwiązaniami oraz wskazano w nich istotne błędy i nieścisłości. 


\section{GENEZA PROJEKTU UTWORZENIA ELEKTRONICZNEJ PLATFORMY GROMADZENIA, ANALIZY I UDOSTĘPNIANIA ZASOBÓW CYFROWYCH O ZDARZENIACH MEDYCZNYCH W KONTEKŚCIE PROCESÓW INTEGRACJ EUROPEJSKIEJ}

Strategia Lizbońska, czyli długofalowy program reform społeczno-gospodarczych przyjęty przez Radę Europejską w 2000 roku, określiła priorytety w zakresie budowy społeczeństwa informacyjnego w Unii Europejskiej. Zgodnie z jej założeniami, zdrowie społeczeństwa zostało określone jako niezbędny warunek wydajności gospodarczej i dobrobytu.

Jednym $z$ elementów budowy społeczeństwa informacyjnego jest e-zdrowie, czyli stosowanie technologii informacyjnych i komunikacyjnych w sektorze opieki zdrowotnej. Powyższe założenie zostało przedstawione w dokumencie eEurope 2005 Information Society for All, przyjętym na szczycie Unii Europejskiej w Sewilli, który nakładał na kraje członkowskie obowiązek rozwinięcia usług elektronicznych, w tym usług w sektorze opieki zdrowotnej.

Szczegółowy plan działań w zakresie e-zdrowia na lata 2004-2010 został określony w komunikacie Komisji Europejskiej z dnia 30 kwietnia 2004 roku (e-Health - making Healthcare bettter for European Citizens: An action plan for a European e-Health Area). Zobowiązuje on kraje członkowskie do podjęcia następujących działań:

- poprawy informacji i wiedzy na temat krajowej opieki zdrowotnej i ubezpieczeń zdrowotnych na terenie całej Wspólnoty,

- promocji e-Health w związku z większą mobilnością zawodową w Unii Europejskiej,

- uruchomienia elektronicznych usług medycznych, takich jak: telekonsultacje, e-recepty, e-skierowania, telemonitoring i teleopieka,

- uruchomienia systemów elektronicznych ubezpieczeń zdrowotnych.

Tak więc władze Unii Europejskiej stoją na stanowisku, iż zastosowanie informatyki w obszarze ochrony zdrowia może przyczynić się do poprawy zdrowia obywateli dzięki nowym usługom zdrowotnym. W kontekście wyzwań demograficznych stojących przed Europą technologie informacyjne mogą pomóc w zwiększeniu wydajności i efektywności publicznych systemów ochrony zdrowia i opieki społecznej.

W 2002 roku decyzją 1786/2002/WE Parlamentu Europejskiego i Rady z dnia 23 września 2002 roku w Programie Działań Wspólnotowych w Dziedzinie Zdrowia Publicznego ustanowiono cel obejmujący gromadzenie, przetwarzanie i analizowanie danych w celu skutecznego monitorowania zdrowia publiczne- 
go oraz w celu uzyskania informacji, które umożliwią formułowanie właściwych strategii, polityk i działań mających na celu osiągnięcie wysokiego poziomu w sektorze opieki zdrowotnej. W szczególności założono:

- poprawę informacji i wiedzy na temat rozwoju zdrowia publicznego,

- poszerzenie zdolności szybkiego i skoordynowanego reagowania na zagrożenia dla zdrowia,

- promocję zdrowia oraz zapobieganie chorobom w drodze ustalenia wyznaczników zdrowia we wszystkich politykach i działaniach.

Wymienione powyżej wytyczne Unii Europejskiej w zakresie konieczności informatyzacji opieki zdrowotnej mają swoje odzwierciedlenie w przepisach krajowych dotyczących budowy społeczeństwa informacyjnego. Do podstawowych regulacji należy zaliczyć:

- Ustawę z dnia 17 lutego 2005 roku o informatyzacji działalności podmiotów realizujących zadania publiczne (Dz. U. nr 64, poz. 565 z późn. zm.),

- Rozporządzenie Rady Ministrów w sprawie Planu Informatyzacji Państwa na lata 2007-2010,

- Strategię rozwoju społeczeństwa informacyjnego w Polsce do roku 2013, która wskazuje Program Informatyzacji Ochrony Zdrowia na liście kluczowych zadań zapewniających realizację celów strategii.

Podobne inicjatywy o celach zbliżonych do Elektronicznej Platformy Gromadzenia, Analizy i Udostępniania Zasobów Cyfrowych o Zdarzeniach Medycznych realizowane są przez inne kraje członkowskie Unii Europejskiej. Przykładowo, w Danii projekt MedCom, w Wielkiej Brytanii Państwowy Program IT Narodowego Systemu Zdrowia (The National Programme for Information Technology), we Włoszech system e-recepta oraz system e-Health card, w Austrii projekt MAGDA-LENA oraz inicjatywa ELGA.

\section{SYTUACJA PRZED WPROWADZENIEM USTAWY O SYSTEMIE INFORMACII W OCHRONIE ZDROWIA}

Pierwszym krokiem poczynionym w celu zinformatyzowania polskiej służby zdrowia i opracowania systemu informacji medycznej było wprowadzenie w 1999 roku na terenie Śląskiej Regionalnej Kasy Chorych systemu START (Standardy Rozliczania Transakcji Medycznych). Główną zmianą, jaką niosło za sobą stworzenie tej platformy, było wprowadzenie na Śląsku kart chipowych dla pacjentów. Zastąpiły one tradycyjne książeczki zdrowia i umożliwiły lekarzowi dostęp do informacji o odbytych wizytach czy przyjmowanych przez pacjenta lekach. System ten działa tam z powodzeniem, jednak ogranicza się tylko do województwa śląskiego. Ułatwia zatem pracę lokalnych placówek służby zdrowia i dostęp do 
odpowiednich danych, jednak nie pomaga to w zbieraniu ogólnopolskich danych epidemiologicznych, tworzeniu programów profilaktycznych czy ocenie potrzeb zdrowotnych Polaków. Dlatego też niezbędne było utworzenie jednego, spójnego, działającego na terenie całej Polski systemu, gromadzącego i udostępniającego odpowiednim jednostkom wszelkich potrzebnych o pacjentach danych.

Aktualnie w polskim prawodawstwie funkcjonuje szereg aktów prawnych poruszających lub stanowiących o informacji i dokumentacji medycznej, ich przetwarzaniu, przekazywaniu, dostępie i ochronie. Są to:

- Ustawa z dnia 18 września 2001 r. o podpisie elektronicznym definiująca pojęcie podpisu elektronicznego, określająca skutki prawne wprowadzenia go w życie, opisująca urządzenia i technologie służące do składania, przechowywania, ochrony i kontroli podpisu;

- Ustawa z dnia 5 lipca 2002 r. o ochronie niektórych usług świadczonych drogą elektroniczną opartych lub polegających na dostępie warunkowym - definiuje ona usługi elektroniczne oraz określa zakazy bezprawnego rozpowszechniania powiązanych $\mathrm{z}$ nimi informacji;

- Ustawa z dnia 27 sierpnia 2004 r. o świadczeniach opieki zdrowotnej finansowanych ze środków publicznych, która wskazuje na obowiązek prowadzenia dokumentacji medycznej, przekazywania przez określone podmioty informacji medycznych, kontroli dokumentacji, a także porusza kwestię dostępności danych usług, czasu oczekiwania na usługę w innych jednostkach;

- Ustawa z dnia 17 lutego 2005 r. o informatyzacji działalności podmiotów realizujących zadania publiczne - główną kwestią dotyczącą elektronicznego systemu informacji medycznej w ustawie jest obowiązek przekazywania i wymiany informacji elektronicznej, o ile taka istnieje, pomiędzy poszczególnymi jednostkami administracyjnymi i innymi podmiotami;

- Ustawa z dnia 21 lipca 2006 r. o zmianie ustawy o ogłaszaniu aktów normatywnych i niektórych innych aktów prawnych oraz ustawy o podpisie elektronicznym, wprowadzająca jedynie niewielką poprawkę do wyżej opisanej ustawy;

- Rozporządzenie Ministra Zdrowia z dnia 10 sierpnia 2001 r. w sprawie rodzajów dokumentacji medycznej w zakładach opieki zdrowotnej, sposobu jej prowadzenia oraz szczegółowych warunków jej udostępniania;

- Rozporządzenie Ministra Zdrowia z dnia 21 grudnia 2010 r. w sprawie rodzajów i zakresu dokumentacji medycznej oraz sposobu jej przetwarzania, określające szczegółowo rodzaje dokumentacji medycznej, możliwości jej przetwarzania, sposoby przekazywania, jej ochronę i kontrolę oraz przypisujące określonym podmiotom obowiązek prowadzenia dokumentacji medycznej w ustalonym zakresie i formie. 
Powyższe regulacje prawne wraz z kilkoma pozostałymi, niewymienionymi powyżej, tworzą możliwość i podstawę do wprowadzenia w życie Ustawy o systemie informacji w ochronie zdrowia.

\section{USTAWA O SYSTEMIE INFORMACJ W OCHRONIE ZDROWIA}

Dnia 25 marca 2011 roku została uchwalona Ustawa o systemie informacji w ochronie zdrowia. Projekt ustawy został przedłożony Sejmowi przez Radę Ministrów 15 października 2010 r. Pierwsze czytanie projektu odbyło się na 77. Posiedzeniu Sejmu w dniu 27 października 2010 r. Następnie projekt był przedmiotem prac sejmowej Komisji Zdrowia. Po kolejnych czytaniach i uchwaleniu ustawy została ona skierowana do Senatu. Ten wprowadził szereg poprawek, spośród których część miała charakter jedynie językowy czy terminologiczny, pozostałe zaś w dużym stopniu ingerowały w treść i przyszłe skutki wprowadzenia Ustawy. Ustawa została podpisana przez Prezydenta i wchodzi w życie $z$ dniem 1 stycznia 2012 roku.

\section{FUNKCJE I ZAŁOŻENIA USTAWY}

Głównymi celami Ustawy o systemie informacji w ochronie zdrowia są:

- Stworzenie warunków informacyjnych umożliwiających podejmowanie w dłuższej perspektywie optymalnych decyzji w zakresie polityki zdrowotnej, niezależnie od przyjętego modelu organizacyjnego opieki zdrowotnej oraz zasad jej finansowania.

- Stworzenie stabilnego systemu informacji w ochronie zdrowia, charakteryzującego się z jednej strony elastycznym podejściem do organizacji systemu zasobów ochrony zdrowia, w tym do modelu finansowania świadczeń ze środków publicznych, z drugiej strony zaś odpornością na zaburzenia w gromadzeniu i archiwizacji danych, spowodowane zmianami systemowymi w ochronie zdrowia.

- Zmniejszenie luki informacyjnej w sektorze ochrony zdrowia, uniemożliwiającej zbudowanie optymalnego modelu opieki zdrowotnej.

- Uporządkowanie istniejącego systemu zbierania, przetwarzania i wykorzystywania informacji w ochronie zdrowia w oparciu o zasady:

- otwartości i interoperacyjności poszczególnych elementów systemu informacji (umożliwienie wymiany danych pomiędzy poszczególnymi elementami systemu informacji w ochronie zdrowia), 
- ograniczania redundancji danych gromadzonych w poszczególnych elementach systemu informacji w ochronie zdrowia,

- wspierania wtórnego wykorzystania danych i informacji gromadzonych przez podmioty publiczne, w tym wykorzystania danych administracyjnych do celów statystycznych,

- funkcjonalizacji i zmniejszenia obciążeń administracyjnych oraz kosztów gromadzenia i wymiany informacji w ochronie zdrowia,

- zapewnienia wysokiego poziomu wiarygodności i jakości danych.

- Poprawienie funkcjonowania opieki zdrowotnej w Rzeczypospolitej Polskiej przez zapewnienie kompleksowości, aktualności, niesprzeczności norm, procesów, systemów i zasobów informacyjnych ochrony zdrowia mających wpływ na zachowanie spójności i ładu informacyjnego w ochronie zdrowia, ze szczególnym uwzględnieniem potrzeb informacyjnych obywateli.

- Optymalizacja nakładów finansowych ponoszonych na informatyzację sektora ochrony zdrowia i rozwój społeczeństwa informacyjnego w obszarze zdrowia względem uzyskiwanych efektów.

- Przywrócenie właściwych relacji pomiędzy wytwórcą danych, gestorami systemów informacyjnych zbierających dane a podmiotami wykorzystującymi i analizującymi informacje generowane w systemach informacyjnych.

Niniejsza ustawa ma za zadanie ograniczyć powielanie danych gromadzonych w poszczególnych elementach systemu oraz wspierać wtórne wykorzystywanie danych i informacji gromadzonych przez podmioty publiczne, w tym wykorzystywanie w celach administracyjnych i statystycznych. Proponuje utworzenie jasnych i przejrzystych podstaw prawnych dla obecnie funkcjonujących i tych, które będą funkcjonować w przyszłości, rejestrów medycznych, elektronicznych dokumentów, takich jak elektroniczne recepty, elektroniczne zwolnienia czy elektroniczne skierowania.

Ustawa wnioskuje również o stworzenie warunków informacyjno-komunikacyjnych, umożliwiających podejmowanie w dłuższej perspektywie optymalnych decyzji w zakresie polityki zdrowotnej, i to niezależnie od przyjętego modelu organizacyjnego opieki zdrowotnej oraz zasad jej finansowania.

W artykule 1 zaproponowano, że powyższa Ustawa określa organizację i zasady działania systemu informacji w ochronie zdrowia, w którym przetwarzane są dane niezbędne do prowadzenia polityki zdrowotnej państwa, podnoszenia jakości i dostępności świadczeń opieki zdrowotnej oraz finansowania zadań z zakresu ochrony zdrowia. Zatem jej wprowadzenie ma za zadanie uporządkować istniejący system zbierania danych, przetwarzania i wykorzystywania informacji w ochronie zdrowia. System ten ma być oparty na otwartości i interoperacyjności poszczególnych elementów systemu i umożliwiać wymianę danych pomiędzy poszczególnymi elementami systemu informacji w ochronie zdrowia. 
System informacji obejmuje bazy danych tworzone przez podmioty zobowiązane do ich prowadzenia, w których znajdują się informacje o:

- udzielonych, udzielanych i planowanych świadczeniach opieki zdrowotnej,

- pracownikach medycznych i usługodawcach, czyli zakładach opieki zdrowotnej oraz osobach fizycznych i jednostkach budżetowych udzielających świadczeń medycznych ${ }^{1}$,

- usługobiorcach - osobach fizycznych uprawnionych do korzystania ze świadczeń opieki zdrowotnej.

Obowiązek prowadzania takich baz danych spoczywa na określonych w Ustawie podmiotach. I tak, udzielone, udzielane i planowane świadczenia zdrowotne powinni ewidencjonować usługodawcy, płatnicy - czyli podmioty finansujące lub współfinansujące dane usługi medyczne, minister właściwy do spraw zdrowia, wojewoda w myśl Ustawy o świadczeniach opieki zdrowotnej finansowanych ze środków publicznych ${ }^{2}$ oraz wszystkie inne podmioty zobowiązane do przetwarzania takich danych. Informacje o usługodawcach i pracownikach medycznych zbierają między innymi organ prowadzący rejestr podmiotów wykonujących działalność leczniczą ${ }^{3}$, wojewoda, minister właściwy do spraw zdrowia, Naczelna Rada Lekarska, wojewódzki inspektor farmaceutyczny i wiele innych. Ostatni rodzaj informacji o usługobiorcach gromadzą wcześniej wspomniani płatnicy oraz usługodawcy.

W systemie informacji przetwarzane są określone przez Ustawę informacje. Obejmują one dane osobowe pacjentów (imię, nazwisko, płeć, obywatelstwo, stan cywilny, wykształcenie, numer PESEL, datę urodzenia, serię i numer dokumentu stwierdzającego tożsamość, adres miejsca zamieszkania, adres e-mail, informację o rodzaju, numerze i terminie ważności uprawnień do świadczeń opieki zdrowotnej i inne) i dane medyczne (historie chorób, odbyte wizyty lekarskie, zażywane leki itp.).Jak widać $\mathrm{z}$ powyższych, część danych służy w oczywisty sposób ewidencji pacjentów i ich chorób, jednak takie dane, jak stan cywilny czy wykształcenie, służyć mają celom statystycznym.

Dodatkowo, w systemie gromadzone będą dane o usługodawcach, płatnikach i pracownikach medycznych, a także ceny udzielonych świadczeń zdrowotnych w celu ich późniejszego rozliczania z płatnikiem.

1 Ustawa z dnia 27 sierpnia 2004 r. o świadczeniach opieki zdrowotnej finansowanych ze środków publicznych, art. 5 pkt 41.

2 Ibidem, art. 10, art. 11 ust. 1.

3 W tym miejscu Senat wprowadził jedną ze swoich poprawek, dodając nieuwzględnioną w początkowej wersji Ustawy frazę „podmiotów wykonujących działalność leczniczą”. 


\section{ZINTEGROWANE SYSTEMY INFORMACJI MEDYCZNEJ}

Tworzony system informacji, poza głównym Systemem Informacji Medycznej, będzie składał się także $\mathrm{z}$ różnych zintegrowanych ze sobą systemów dziedzinowych w celu filtracji i odpowiedniego podziału danych i odczytania tylko tych potrzebnych dla danej jednostki.

W Ustawie zostały wyodrębnione:

- System Rejestru Usług Medycznych Narodowego Funduszu Zdrowia - system teleinformatyczny, którego celem jest przetwarzanie danych o udzielonych i planowanych świadczeniach opieki zdrowotnej finansowanych ze środków publicznych oraz rozliczanie tych świadczeń;

- System Statystyki w Ochronie Zdrowia służący do przetwarzania danych statystycznych z zakresu ochrony zdrowia;

- System Ewidencji Zasobów Ochrony Zdrowia - gdzie przetwarzane i ewidencjonowane są dane usługodawców, płatników oraz podmiotów kontrolujących ich działalność;

- System Wspomagania Ratownictwa Medycznego gromadzący i udostępniający dane o Państwowym Ratownictwie Medycznym - umożliwiający ewidencję i rejestr jednostek systemu, centrów urazowych, podmiotów prowadzących kursy kwalifikowanej pierwszej pomocy i innych ${ }^{4}$;

- System Monitorowania Zagrożeń - mający za zadanie poprawić efektywność działań w zakresie zapobiegania skutkom zdarzeń niepożądanych wpływających na zdrowie i życie człowieka, dodatkowo w ramach którego działa resortowy system wczesnego ostrzegania o takich zdarzeniach;

- System Monitorowania Dostępności do Swiadczeń Opieki Zdrowotnej przetwarzane są tu dane i informacje o liczbie oczekujących na dane świadczenia i dostępności tych świadczeń;

- System Monitorowania Kosztów Leczenia i Sytuacji Finansowo-Ekonomicznej Podmiotów Leczniczych, którego zadaniem jest gromadzenie i przetwarzanie danych o kosztach leczenia w zakresie świadczeń opieki zdrowotnej finansowanych ze środków publicznych oraz danych o sytuacji ekonomiczno-finansowej podmiotów leczniczych;

- Zintegrowany System Monitorowania Obrotu Produktami Leczniczymi - gromadzący informacje o obrocie produktami leczniczymi w Polsce, w szczególności dane o dostarczaniu, a także o ilości i rodzaju kupowanych, sprzedawanych i sporządzanych produktach leczniczych ${ }^{5}$;

4 Ustawa z dnia 8 września 2006 r. o Państwowym Ratownictwie Medycznym, art. 17 i 23 ust. 1.

Ustawa z dnia 6 września 2001 r. Prawo farmaceutyczne, art. 78 ust. 3 i art. 95 ust. 4 pkt 8. 
- System Monitorowania Kształcenia Pracowników Medycznych wskazujący zapotrzebowanie na szkolenia w określonych dziedzinach medycyny i farmacji, monitoruje kształcenie podyplomowe i wspomaga zarządzanie systemem szkoleń;

- rejestry medyczne.

System Informacji Medycznej (SIM) ma być obsługiwany przez dwa różniące się funkcjami i zadaniami systemy teleinformatyczne - Platformę Udostępniania On-Line Usług i Zasobów Cyfrowych Rejestrów Medycznych (PUU) oraz Elektroniczną Platformę Gromadzenia, Analizy i Udostępnienia Zasobów Cyfrowych o Zdarzeniach Medycznych (EPG).

Pierwszy z nich, PUU, umożliwiać będzie komunikowanie się Systemu Informacji Medycznej z rejestrami medycznymi w celu pozyskiwania przetwarzanych w nich danych, dokonywanie aktualizacji danych w rejestrach medycznych, a także udostępnianie usługodawcom i płatnikom danych z rejestrów medycznych i ich integrację. Administratorem tego systemu będzie jednostka podległa ministrowi właściwemu do spraw zdrowia, której zadaniem będzie zarządzanie i utrzymywanie systemu PUU.

System EPG jest bardziej złożony i będzie pełnił więcej funkcji związanych z przetwarzaniem danych medycznych, obejmujących m.in.:

- dostęp usługobiorców do informacji o udzielonych i planowanych świadczeniach opieki zdrowotnej zgromadzonych w SIM oraz raportów z udostępnienia danych ich dotyczących;

- przekazywanie przez usługodawców do SIM informacji o udzielonych, udzielanych i planowanych świadczeniach opieki zdrowotnej;

- wymianę pomiędzy usługodawcami danych zawartych w elektronicznej dokumentacji medycznej;

- wymianę dokumentów elektronicznych pomiędzy usługodawcami w celu prowadzenia diagnostyki, zapewnienia ciągłości leczenia oraz zaopatrzenia pacjentów w produkty lecznicze i wyroby medyczne;

- dostęp podmiotów prowadzących rejestry medyczne do danych przetwarzanych w SIM za pośrednictwem Platformy Udostępniania On-Line Usług i Zasobów Cyfrowych Rejestrów Medycznych;

- dostęp jednostek samorządu terytorialnego do danych przetwarzanych w SIM w celu zapewnienia mieszkańcom równego dostępu do świadczeń opieki zdrowotnej;

- dostęp wojewodów do danych niezbędnych do realizacji powierzonych im ustawowo zadań6;

6 Ustawa z dnia 27 sierpnia 2004 r. o świadczeniach opieki zdrowotnej finansowanych ze środków publicznych, art. 10 . 
- dostęp ministra właściwego do spraw zdrowia do danych niezbędnych do realizacji określonych zadań ${ }^{7}$.

Podobnie jak w przypadku poprzedniego systemu, administratorem będzie jednostka podległa ministrowi właściwemu do spraw zdrowia.

W artykule 9 Ustawy zaznaczone jest, że minister właściwy do spraw zdrowia po porozumieniu z Szefem Agencji Bezpieczeństwa Wewnętrznego i Szefem Agencji Wywiadu wyda rozporządzenie, w którym określone będą szczegółowe zasady działania tych systemów, aby zapewnić bezpieczeństwo zgromadzonych $\mathrm{w}$ nich danych i ochronę przed nieuprawnionym dostępem.

Ustawa określa również uprawnienia i dostęp różnych podmiotów do poszczególnych danych. I tak, pacjenci będą mogli używać danych osobowych i danych medycznych niezbędnych do monitorowania swojego stanu zdrowia i jego poprawy. Usługodawcom i pracownikom medycznym przysługuje natomiast dostęp do danych potrzebnych do zapewnienia ciągłości leczenia pacjentów oraz niezbędnej wymiany danych pomiędzy poszczególnymi podmiotami. Uprawnienia takie są określone także dla wojewodów, płatników, jednostek samorządu terytorialnego czy podmiotów prowadzących rejestry medyczne. Oczywiście korzystanie z tych przywilejów jest nieodpłatne.

Tak samo jak w przypadku szczegółowego funkcjonowania systemów, format elektronicznej dokumentacji medycznej i warunki jej przetwarzania zostaną dokładnie określone w drodze rozporządzenia.

Jedne $\mathrm{z}$ integralnych elementów Systemu Informacji Medycznej stanowić będą rejestry medyczne. Rejestry zawierać będą ewidencję, listę, spis albo inny uporządkowany zbiór danych osobowych lub jednostkowych danych medycznych, czyli wszystkich informacji niezbędnych do udzielania świadczeń opieki zdrowotnej oraz o stanie zdrowia. Zgodnie z Ustawą, tworzy się następujące rejestry:

- Centralny Wykaz Usługobiorców, w którym gromadzone będą wszelkie dane osobowe, dane dotyczące uprawnień do korzystania ze świadczeń opieki zdrowotnej oraz przechowywany będzie unikalny identyfikator nadany każdemu pacjentowi;

- Centralny Wykaz Usługodawców - znajdą się tu wszelkie dane świadczeniodawców;

7 Ibidem, art. 11 ust. 1. 


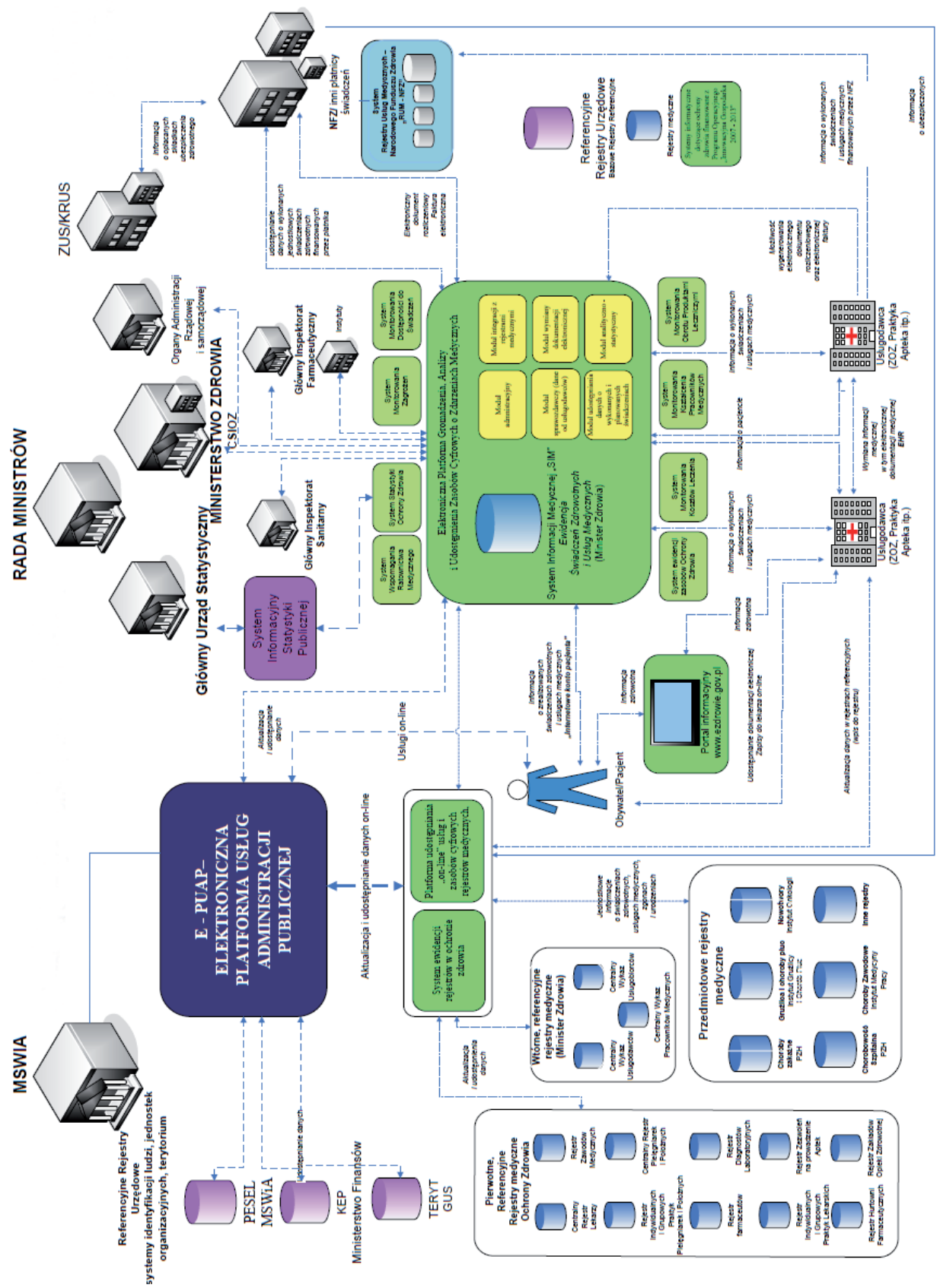

Rysunek 1. System informacji w ochronie zdrowia wg Ustawy o informacji w ochronie zdrowia Źródło: http://www.mz.gov.pl. 
- Centralny Wykaz Pracowników Medycznych - zawierający dane personalne, numer prawa wykonywania zawodu, informacje o specjalizacjach oraz o nadanym certyfikacie - elektronicznym zaświadczeniu, za pomocą którego dane służące do weryfikacji podpisu elektronicznego są przyporządkowane do osoby składającej podpis elektroniczny, które umożliwiają identyfikację tej osoby ${ }^{8}$ oraz pozwalają na autoryzację i dostęp do danych pacjenta.

Na podstawie danych zgromadzonych w Systemie Informacji Medycznej minister właściwy do spraw zdrowia może zlecić monitorowanie zapotrzebowania na świadczenia opieki zdrowotnej, monitorowanie stanu zdrowia pacjentów oraz prowadzenie profilaktyki zdrowotnej i realizację programów zdrowotnych. Działania takie rozpoczynają się w drodze rozporządzenia, w którym określony musi być ich cel, okres, z którego dane mają być pobrane, oraz ich zakres. Natomiast ich wyniki publikowane są w prowadzonym przez ministra Biuletynie Informacji Publicznej.

\section{INNE FUNKCJE I ROZWIĄZANIA}

Zgodnie z postanowieniami Ustawy o ochronie danych osobowych, pacjent ma prawo do nieograniczonego dostępu do swoich danych, a także może decydować o ich przepływie oraz udostępnianiu. Ma on również prawo do niewyrażania zgody na udostępnienie swoich danych, poza sytuacją, w której dane te są niezbędne płatnikowi do oceny dostępności do świadczeń opieki zdrowotnej lub działań związanych ze zwalczaniem chorób zakaźnych i zakażeń. $\mathrm{Na}$ wniosek pacjenta administrator systemu ma obowiązek przesłać określone dane w postaci elektronicznej lub papierowej.

Elementem dodatkowym, niejako uzupełniającym cały System Informacji Medycznej, ma być utworzony przez ministra właściwego ds. zdrowia portal edukacyjno-informacyjny, w którym zamieszczane mają być informacje na temat obsługi i zasad systemu oraz wszelkie statystyki, raporty i analizy dotyczące systemu, a także bazy danych szkoleń dla pracowników medycznych i kadry zarządzającej.

Minister zdrowia może kontrolować funkcjonowanie całego systemu: osiąganie założonych celów, legalność i rzetelność prowadzonych baz danych i przekazywania zawartych w nich informacji oraz zlecać naprawę ewentualnie wykrytych nieprawidłowości. Przeprowadzenie takiej kontroli może zlecać zewnętrznym instytutom badawczym, ale w głównej mierze wykonywać ją powinni pracownicy urzędu ministra zdrowia lub osoby przez niego upoważnione. Osoby te są

\footnotetext{
8 Ustawa z dnia 18 września 2001 r. o podpisie elektronicznym, art. 3 pkt 10.
} 
uprawnione do wglądu do wszelkich baz danych w zakresie ochrony zdrowia oraz dokumentów związanych z działalnością kontrolowanego podmiotu. Jednak w przypadku, gdy chodzi o dostęp do danych medycznych i dokumentacji medycznej, dostęp do nich mogą mieć jedynie osoby wykonujące zawód medyczny odpowiedni do kontrolowanych informacji. Kontrolerzy mają bezwzględny obowiązek zachowania tajemnicy poznanych informacji, a wykorzystywać je można tylko i wyłącznie w sposób uniemożliwiający identyfikację pacjenta.

Dodatkowo, niezależnie od zaleceń ministra zdrowia odnośnie do dodatkowych kontroli, istnieją jednostki podległe ministrowi sprawujące nadzór nad funkcjonowaniem i bezpieczeństwem baz danych gromadzonych w systemie, a także prowadzące stały audyt rejestrów medycznych i systemów informatycznych.

Ustawa wprowadza zmiany w wielu wcześniej funkcjonujących aktach prawnych. Są to m.in.:

- ustawa o zawodzie felczera,

- ustawa o Państwowej Inspekcji Sanitarnej,

- ustawa o samorządzie pielęgniarek i położnych,

- ustawa o izbach aptekarskich,

- ustawa o zawodach lekarza i lekarza dentysty,

- ustawa o świadczeniach pieniężnych z ubezpieczenia społecznego w razie choroby i macierzyństwa,

- ustawa o diagnostyce laboratoryjnej,

- ustawa Prawo farmaceutyczne,

- ustawa o świadczeniach opieki zdrowotnej finansowanych ze środków publicznych,

- ustawa o prawach pacjenta i Rzeczniku Praw Pacjenta,

- ustawa o izbach lekarskich,

- ustawa o wyrobach medycznych.

We wszystkich powyższych ustawach dodany został zapis mówiący, że wszelkie informacje dotyczące dziedziny, do której odnosi się dana ustawa, muszą zostać udostępnione systemowi informacji w ochronie zdrowia. Dodatkowo, jednostki zarządzające daną dziedziną zobowiązane są prowadzić i udostępniać rejestry pracowników. Ustawa wprowadza również pewne zmiany w poszczególnych ustawach. Przykładowo, obowiązek zgłaszania przez lekarza działań niepożądanych leków musi być realizowany elektronicznie, wszelkie inne rejestry, takie jak rejestr zezwoleń na prowadzenie hurtowni farmaceutycznej czy rejestr zezwoleń na prowadzenie aptek ogólnodostępnych oraz szpitalnych, również muszą być prowadzone w wersji elektronicznej w systemie teleinformatycznym jako część systemu informacji medycznej. W Ustawie z dnia 27 sierpnia 2004 r. o świadczeniach opieki zdrowotnej finansowanych ze środków publicznych dodane zostały zapisy o obowiązku umożliwienia przez świadczeniodawców umawiania pacjen- 
tów na wizyty drogą elektroniczną, monitorowania statusu na liście oczekujących na daną wizytę oraz przekazywania informacji o tej liście do systemu.

\section{ZASTRZEŻENIA I PROPONOWANE ZMIANY}

Od momentu opracowania projektu Ustawy o systemie informacji w ochronie zdrowia akt ten spotykał się i nadal się spotyka $z$ licznymi zastrzeżeniami i uwagami. Dokument pozostawia bowiem wiele niejasności, często po prostu przez niedoprecyzowane stwierdzenia i opisy poruszanych kwestii.

\section{ZASTRZEŻENIA GIODO I KOMISJI ZDROWIA}

Już pierwsze organy mające do czynienia z projektem, Generalny Inspektor Ochrony Danych Osobowych oraz Komisja Zdrowia, miały wiele uwag do proponowanej Ustawy. Stwierdzono, że artykuły 19 i 20 mogą naruszać Konstytucję Rzeczypospolitej Polskiej. Wspomniane artykuły przewidują, że podstawą prawną do tworzenia rejestrów medycznych w przyszłości będzie rozporządzenie ministra zdrowia, a nie ustawa. Taka regulacja może nie zapewnić gwarancji ochrony praw pacjentów i nie zabezpieczyć ich przed nadmierną ingerencją państwa w sferę życia prywatnego, która jest chroniona na mocy art. 47 Konstytucji. Dodatkowo, może ona naruszać art. 51 Konstytucji, który jest barierą dla władz publicznych do swobodnego zdobywania i udostępniania danych osobowych obywateli. Ponadto, w ust. 1 tego artykułu określone zostało, że nikt nie może być zobowiązany do ujawniania informacji osobowych inaczej niż na podstawie ustawy. Wydawać by się mogło, że nie stoi to w sprzeczności z wchodzącą w życie Ustawą, jednak należy zwrócić uwagę, że bardzo wiele poruszonych w niej i niedoprecyzowanych kwestii ma być określonych za pomocą rozporządzeń. Pomijając fakt, że opracowanie i wprowadzenie w życie rozporządzenia może nie zostać tak szczegółowo skontrolowane przez inne organy jak ustawa, a przez to tym bardziej może zawierać wiele niedoprecyzowanych kwestii, a nawet sprzeczności, to sytuacja ta jest w sposób oczywisty sprzeczna $\mathrm{z}$ zapisem konstytucyjnym. Można postawić również tezę, iż jeśli rejestry medyczne będą tworzone na podstawie rozporządzenia, decyzję o powstaniu samego rejestru, zakresie danych, a także o sposobie ich zabezpieczenia będzie podejmował minister zdrowia, który reprezentuje interesy resortu, a nie parlament - przedstawiciel społeczeństwa. Istnieje zatem ryzyko, że rejestry medyczne będą powstawać i działać poza społeczną kontrolą. Zaznaczyć należy, że artykułów i ustępów, w których powiedziane jest, że pewne zagadnienia zostaną uregulowane i sprecyzowane w drodze rozporządzenia, jest aż 18 , a przecież treść samej Ustawy nie jest obszerna. 
Dane medyczne są chronione w Polsce przez Ustawę o ochronie danych osobowych $^{9} \mathrm{i}$ prawo europejskie ${ }^{10}$, w którym powiedziane jest, że państwa członkowskie zabraniają przetwarzania danych osobowych dotyczących zdrowia. Dodatkowo dane medyczne chroni tajemnica lekarska, a także zasady etyki zawodowej lekarzy. Dane medyczne są chronione na wielu poziomach, ponieważ niewłaściwe ich przetwarzanie może powodować szczególne ryzyko dla praw podstawowych, prowadzić do dyskryminacji (np. w stosunkach z pracodawcami) i nieodwracalnych szkód. W dodatku dane te mają wymierną wartość rynkową (np. dla firm ubezpieczeniowych), co sprawia, że sektor medyczny jest szczególnie narażony na różnego rodzaju ataki (np. hakerskie) i wycieki danych.

\section{POZOSTAŁE ZASTRZEŻENIA}

Kolejne, bardziej szczegółowe zastrzeżenia wobec Ustawy to:

- Ustawa nie określa precyzyjnie, jaki zakres danych będzie gromadzony w systemie. Nie wskazuje bowiem jasno podstawy prawnej, w oparciu o którą dane medyczne mają do niego trafiać. Część z nich znajdzie się tam na podstawie ustawy, część na podstawie aktów niższego rzędu (rozporządzeń). Niektóre rejestry, które mają stać się elementem systemu, istnieją $\mathrm{w}$ ogóle bez podstawy prawnej. Jednocześnie ministrowi zdrowia przyznana została kompetencja do tworzenia kolejnych rejestrów w drodze rozporządzenia;

- Nie wiadomo, w jaki sposób i w jakim zakresie przetwarzane dane będą objęte systemem. Ustawa przewiduje gromadzenie danych w trzech modułach: podstawowym, statystyczno-rozliczeniowym i zleceń. Jednak opis modułów i ich funkcjonalność, a co za tym idzie podstawowe zasady postępowania $\mathrm{z}$ informacjami $\mathrm{w}$ nich zawartymi zostaną uregulowane dopiero w aktach wykonawczych;

- W Ustawie brakuje precyzyjnego określenia kręgu podmiotów, które będą miały dostęp do danych medycznych oraz podstaw prawnych i zasad, na jakich ma się to odbywać. Osobami upoważnionymi do dostępu do danych pacjenta powinni być jedynie lekarze sprawujący bezpośrednią opiekę nad chorym. Niedopuszczalne jest, aby ten sam zakres dostępu miał inny personel medyczny czy administracyjny danej placówki;

- Ustawa bardzo ogólnie określa zasady odpowiedzialności i kontrolę nad funkcjonowaniem systemu przez ministra zdrowia. Tymczasem istotne

9 Ustawa z dnia 29 sierpnia 1997 r. o ochronie danych osobowych, art. 27 ust. 7.

10 Dyrektywa 95/46/WE, art. 8. 
znaczenie ma ustalenie jasnych zasad bezpośredniej odpowiedzialności osób, które mają dostęp do danych, a także konieczność prowadzenia odpowiednich szkoleń dla personelu medycznego z zakresu prawnych i technologicznych aspektów dbałości o bezpieczeństwo danych medycznych. Aby zminimalizować ryzyko zagrożeń dla prywatności pacjentów, niezbędne jest wypracowanie i zharmonizowanie odpowiednich ram prawnych oraz standardów technologicznych chroniących prywatność, takich jak odpowiedni system uwierzytelniania użytkownika, szyfrowanie danych, stosowanie programów antywirusowych itp.;

- Wątpliwości może wywoływać również używana terminologia. W projekcie rozdzielono np. pojęcia danych osobowych oraz jednostkowych danych medycznych, co może sugerować, że te ostatnie nie stanowią danych osobowych i dodatkowo, że w ochronie zdrowia obowiązują inne zasady ochrony danych niż te wynikające z Ustawy o ochronie danych osobowych;

- Kwestią mogącą budzić zastrzeżenia są także ustalenia co do kontroli systemu przez ministra zdrowia. Będą ją sprawować osoby przez niego upoważnione, a nie niezależne jednostki kontrolujące. Może to powodować podejrzenia co do rzetelności i obiektywności przeprowadzanych kontroli, ich stosowności i pobieranych $\mathrm{z}$ ich tytułu wynagrodzeń - dwukrotności kwoty przewidzianej dla osób zajmujących kierownicze stanowiska państwowe.

\section{ZMIANY W PROJEKCIE USTAWY}

Mówiąc o bardziej sprecyzowanych zastrzeżeniach, nie sposób nie wspomnieć o konkretnych zmianach wprowadzonych w treści projektu Ustawy przed jej ogłoszeniem 25 marca 2011 roku. Wiele z nich miało charakter jedynie językowy i stylistyczny - zmiany form poszczególnych wyrazów, usunięcie czy dodanie przecinka i tym podobne. Było jednak kilka obszerniejszych, dodających stosunkowo dużą ilość tekstu i wiele zmieniających, z których najważniejsze to:

- W artykule 19 mówiącym o monitorowaniu zapotrzebowania na świadczenia opieki zdrowotnej oraz stanu zdrowia pacjentów przez ministra właściwego do spraw zdrowia dodano ust. 1a. Wynika z niego, że minister zdrowia może zlecić prowadzenie tych rejestrów podmiotom wykonującym działalność leczniczą oraz jednostkom mu podległym;

- Ten sam artykuł wzbogacono o ust. 7 i 8, w których określone zostało, że dane niezbędne do prowadzenia takiego monitoringu przekazywać muszą usługodawcy i podmioty prowadzące rejestry publiczne i medyczne. Bardzo ważna jest treść ust. 8 mówiąca o obowiązku podmiotu 
prowadzącego rejestr do poinformowania o tym w ciągu 30 dni każdej osoby, której dotyczą przetwarzane dane. Dodatkowo musi on uzyskać zgodę pacjenta na ich przetwarzanie lub poinformować go o obowiązku podania danych. W drugim przypadku musi także zapoznać pacjenta z podstawą prawną do takiego postępowania;

- W art. 24 w ust. 2 dodany został pkt 4 mówiący o danych usługodawców przetwarzanych w Systemie Ewidencji Zasobów Ochrony Zdrowia wzbogaconych o informacje o wyrobach medycznych, czyli wszelkich narzędziach, urządzeniach, materiałach i innych stosowanych w celach diagnostycznych i terapeutycznych ${ }^{11}$;

- Art. 39 otrzymał dodatkowy ust. 11a, w którym mowa jest o obowiązku ministra zdrowia wydania zalecenia nakazującego usunięcie nieprawidłowości wykrytych podczas kontroli baz danych.

\section{ZAKOŃCZENIE}

Założenia wprowadzonej Ustawy o systemie informacji w ochronie zdrowia są korzystne, zarówno dla pojedynczego pacjenta, jak i dla całego systemu ochrony zdrowia w Polsce. Łatwiejszy dostęp do usług zdrowotnych, możliwość zapisów przez Internet, wgląd do wyników badań, ewidencja odbytych wizyt i przyjmowanych leków, ułatwienie rozliczeń za usługi zdrowotne czy o wiele szerszy dostęp do danych służących opracowaniom statystycznym to tylko niektóre wypływające z niej korzyści.

Jak jednak zostało powyżej przedstawione, w przyjętej Ustawie nadal pozostaje wiele niedoprecyzowanych kwestii, a nawet takich, które budzą poważne zastrzeżenia i obawy.

Negatywną konsekwencją przyjęcia Ustawy może być stworzenie systemu, który nie będzie wystarczająco przejrzysty i nie będzie spełniał wymaganych kryteriów bezpieczeństwa. To natomiast będzie skutkować brakiem zaufania pacjentów i dużym rozczarowaniem. Doświadczenia innych krajów, takich jak na przykład Niemcy i wprowadzony tam w 2008 roku system informacji medycznej oraz liczne, związane z tym protesty, pokazują, że wprowadzanie systemów informacji medycznej jest niezwykle skomplikowane i nierzadko może zakończyć się niepowodzeniem. Dlatego polski system powinno wprowadzać się z rozwagą, mając pewność, że jest on dobrze przygotowany oraz że istnieje wystarczająco dużo czasu na jego wdrożenie. Nałożone przez Unię Europejską ograniczenie w postaci konieczności wprowadzenia systemu do 2014 roku zdecydowanie nie

11 Ustawa z dnia 20 maja 2010 r. o wyrobach medycznych, art. 2 ust. 1 pkt 38. 
daje poczucia stabilności czasowej. Nie jest to bynajmniej spowodowane zbyt krótkim czasem przeznaczonym na zmiany, a brakiem reakcji ze strony Polski na zalecenia wydane już kilka lat temu.

Być może część $\mathrm{z}$ wyżej przedstawionych zarzutów może wydawać się przesadzona, jednak do ustawy w tak dużym stopniu zmieniającej dotychczasowy system funkcjonowania polskiej służby zdrowia oraz tak bardzo narażającej na ryzyko dane osobowe pacjentów trzeba podchodzić krytycznie, aby możliwie w jak największym stopniu wyeliminować jej niedociągnięcia i wynikające z niej potencjalne zagrożenia dla całego polskiego społeczeństwa.

\section{ŹRÓDŁA}

Konstytucja Rzeczypospolitej Polskiej, http://www.sejm.gov.pl.

Opinia do ustawy o systemie informacji w ochronie zdrowia (druk nr 1156), http://www. senat.gov.pl.

Rozporządzenie Ministra Zdrowia z dnia 10 sierpnia 2001 r. w sprawie rodzajów dokumentacji medycznej w zakładach opieki zdrowotnej, sposobu jej prowadzenia oraz szczegółowych warunków jej udostępniania, http://www.nfz-poznan.pl.

Rozporządzenie Ministra Zdrowia z dnia 21 grudnia 2010 r. w sprawie rodzajów i zakresu dokumentacji medycznej oraz sposobu jej przetwarzania, http://www.bil.bielsko.pl.

Sprawozdanie Komisji Zdrowia z dnia 13 kwietnia 2011 r., druk nr 1156 Z, http://www. sejm.gov.pl.

Uchwała Senatu Rzeczypospolitej Polskiej z dnia 14 kwietnia 2011 r. w sprawie Ustawy o systemie informacji w ochronie zdrowia, http://www.senat.gov.pl.

Ustawa z dnia 29 sierpnia 1997 r. o ochronie danych osobowych, http://www.giodo.gov.pl. Ustawa z dnia z dnia 6 września 2001 r. Prawo farmaceutyczne, http://www.gif.gov.pl.

Ustawa z dnia 18 września 2001 r. o podpisie elektronicznym, http://biuletyn.net.

Ustawa z dnia 5 lipca 2002 r. o ochronie niektórych usług świadczonych drogą elektroniczną opartych lub polegających na dostępie warunkowym, http://www.uokik.gov.pl.

Ustawa $\mathrm{z}$ dnia 27 sierpnia 2004 r. o świadczeniach opieki zdrowotnej finansowanych ze środków publicznych, http://lex.pl.

Ustawa z dnia 17 lutego 2005 r. o informatyzacji działalności podmiotów realizujących zadania publiczne, http://www.bip.gov.pl.

Ustawa z dnia 21 lipca 2006 r. o zmianie ustawy o ogłaszaniu aktów normatywnych i niektórych innych aktów prawnych oraz ustawy o podpisie elektronicznym, http://www. nettax.pl.

Ustawa z dnia 8 września 2006 r. o Państwowym Ratownictwie Medycznym, http://isap. sejm.gov.pl.

Ustawa z dnia 20 maja 2010 r. o wyrobach medycznych, http://www.legeo.pl.

Ustawa z dnia 25 marca 2011 r. o systemie informacji w ochronie zdrowia, http://prawoimedycyna.pl.

http://biblioteka.mwi.pl.

http://www.ezdrowie.gov.pl. 
http://www.gazetaprawna.pl.

http://www.mz.gov.pl.

http://www.portalsamorzadowy.pl.

http://www.sluzbazdrowia.com.pl.

http://www.uniaeuropejska.net.pl.

\section{STRESZCZENIE}

Dnia 25 marca 2011 roku została uchwalona Ustawa o systemie informacji w ochronie zdrowia. Wchodzi ona w życie 1 stycznia 2012 roku. Ustawa zakłada utworzenie Systemu Informacji Medycznej (SIM), który umożliwi dostęp do informacji o udzielonych i planowanych świadczeniach zdrowotnych. Dane te będą przetwarzane i udostępniane w postaci elektronicznej. Elementem systemu teleinformatycznego przeznaczonym do obsługi SIM będzie Elektroniczna Platforma Gromadzenia, Analizy i Udostępnienia Zasobów Cyfrowych o Zdarzeniach Medycznych. Umożliwi ona dostęp do informacji o udzielonych i planowanych świadczeniach opieki zdrowotnej. Pozwoli również na wymianę danych zawartych w elektronicznej dokumentacji medycznej niezbędnej do zapewnienia ciągłości leczenia lub prowadzonego postępowania diagnostycznego. Założenia Ustawy są korzystne, zarówno dla pojedynczego pacjenta, jak i dla całego systemu ochrony zdrowia w Polsce. Łatwiejszy dostęp do usług zdrowotnych, możliwość zapisów przez Internet, wgląd do wyników badań, ewidencja odbytych wizyt i przyjmowanych leków, ułatwienie rozliczeń za usługi zdrowotne czy o wiele szerszy dostęp do danych służących opracowaniom statystycznym to tylko niektóre wypływające z niej korzyści. W przyjętej Ustawie nadal jednak pozostaje wiele niedoprecyzowanych kwestii, a nawet takich, które budzą poważne zastrzeżenia i obawy. Eksperci twierdzą, iż konsekwencją Ustawy może być stworzenie systemu, który nie będzie wystarczająco przejrzysty i nie będzie spełniał wymaganych kryteriów bezpieczeństwa gromadzonych danych. To natomiast z pewnością będzie skutkować brakiem zaufania pacjentów i dużym rozczarowaniem.

\section{AN ELECTRONIC PLATFORM FOR GATHERING, ANALYSIS AND DISTRIBUTION OF DIGITAL RESOURCES ON MEDICAL EVENTS IN THE LIGHT OF THE LAW ON THE INFORMATION SYSTEM IN HEALTHCARE}

\section{SUMMARY}

The new bill on the Information System in Healthcare was passed by the Polish Parliament on March 25, 2011. It will come into force on Jan $1^{\text {st }} 2012$. According to the new Law, The Medical Information System will be created. It will enable users to find out electronic information about performed and planned healthcare services. It will also make it possible to exchange information necessary for the continuity of diagnostic and treatment procedures between different healthcare providers. The new Law seems to be beneficial for individual patients as well as for the whole healthcare system in Poland. Easier access to healthcare services, on-line visits booking, access to laboratory results, 
history of treatment and prescribed drugs are the most important patient's benefits. The benefits for the healthcare system include easier access to the databases for statistical computations and a more unified system of financial settlements. Regardless of the many benefits of the new Law, there are some uncertainties causing serious concerns. Jeopardized data safety and lack of transparency are the issues most often brought up by the experts. This may result in patients' lack of trust and, finally, disappointment. 
